\title{
Starting a Community Garden ${ }^{1}$
}

\section{Eva C. Worden, Adrian Hunsberger, and John McLaughlin ${ }^{2}$}

A community garden is a collaborative greenspace in which the participants share in both the maintenance and the rewards. There is a long tradition of community gardening in various parts of the United States and around the world. This publication has been developed to assist those who wish to form a community garden in Florida.

\section{Why Get Involved with Community Gardening?}

Reasons abound for involvement in community gardening, including the chance to:

- Increase self-esteem, bolster confidence and encourage learning in children

- Create beauty

- Provide positive work experiences for at-risk youth

- Grow fresh produce

- Improve nutrition and fitness

- Share the joys and wonders of gardening
- Promote healthier communities

- Be neighborly

- Reduce stress

- Reduce crime

- Have fun

\section{Who Gets Involved in Community Gardening?}

Many different groups are involved in community gardening, including:

- Homeowner associations

- Neighborhood block groups

- Religious organizations

- Primary and secondary schools

- Colleges and universities

- Social service agencies

- Health care facilities

1. This document is ENH 966, one of a series of the Environmental Horticulture Department, Florida Cooperative Extension Service, Institute of Food and Agricultural Sciences, University of Florida. Original publication date June 28, 2002. Reviewed: October 2003. Visit the EDIS web site at http://edis.ifas.ufl.edu.

2. Eva C. Worden, Assistant Professor and Extension Specialist, Environmental Horticulture, Fort Lauderdale Research and Education Center; Adrian Hunsberger, Urban Horticulture Extension Agent, Miami-Dade County; John McLaughlin, Extension Program Assistant, Miami-Dade County.

The Institute of Food and Agricultural Sciences is an equal opportunity/affirmative action employer authorized to provide research, educational information and other services only to individuals and institutions that function without regard to race, color, sex, age, handicap, or national origin. For information on obtaining other extension publications, contact your county Cooperative Extension Service office. Florida Cooperative Extension Service/Institute of Food and Agricultural Sciences/University of Florida/Christine Taylor Waddill, Dean. 
- Correctional institutions

- Corporations

- Gardening clubs

\section{Management Approaches}

Management approaches to community gardens can be classified into two major categories: 1) individual plots, and 2) common greenspace.

In the individual plot approach, the garden is subdivided for personal use, as in the "allotment" system common in the United Kingdom. Individual plots can be chosen, randomly selected, or assigned. Individual plot management often is used for vegetable gardening.

In the common greenspace approach, garden members cooperate in managing one area. Often, each member is responsible for a set of tasks within the shared area. Common greenspace management is used for a variety of garden types. Some examples include:

- Ornamental landscapes: pocket parks, community beautification; clean-up of degraded urban landscapes

- Educational gardens: used for job training, horticultural demonstrations, outdoor classrooms

- Entrepreneurial gardens: profits from the sales of garden products are shared among members

\section{Getting Started}

Planning and communication at the outset of a community garden project often helps to avoid problems in the future. Some key questions to be considered early on in garden development include:

Is there sufficient interest? The interest must come from the individuals who actually will be using the garden - not just from well-meaning supporters.

What are the group's purposes and goals? To provide a source of fresh food crops? To beautify the location? To foster a greater sense of community and cooperation? Have a group brainstorming session where all dreams are welcome - then sort out the priorities and practical alternatives.

Where will the garden be located? One of the first practical tasks will be to secure a usable plot of land. This could be leased from or donated by a private individual or organization. Another option is to use city- or county-owned land. The area to be used as a garden should have a reliable source of water.

Is the land tenure secure? Land tenure refers to the rights of access to and use of real estate. If the community garden site lacks secure land tenure, the members risk losing the property in the future. If the gardening group does not own the land, try to get a long-term written lease, even if there is no fee for using the land.

\section{How will the property be planted and} maintained? Draw up a master plan, showing how each section of the garden will be developed. Discuss and decide on using individually managed plots versus common growing areas.

\section{What tasks need to be done? Who will do} them? Determine whether there will be employees or member volunteers. It can be helpful to have one person who will act as a general garden coordinator. This individual would serve as the contact person for any initial interactions with external agencies (i.e., local authorities, local businesses, or private foundations).

You may want to create subcommittees to manage the many tasks involved with getting the garden "off the ground." Some subcommittees might be:

- Site acquisition and land tenure

- Garden layout and master planning

- Site preparation and workdays

- Finances and fundraising

- Communications and social events

Consider allowing members to choose their responsibilities from a list of tasks. Leftover tasks can be tackled on group workdays or by teams. 
How do you want to operate? Write a set of guidelines or by-laws to convey the groups expectations for behavior (e.g., hours that the garden is open, fees for membership).

What are the garden's financial needs? Create a budget. Include costs for site clearing, soil improvement and the purchase of tools and structures (i.e., raised beds, irrigation equipment, tool storage shed, arbors, pergolas or a chickee).

How will funds be raised? Monies can be obtained through a variety of ways - fund-raising drives, such as plant sales; sponsorships of local businesses; grants from government agencies or private foundations.

What are the legal issues? Consider the legal issues, such as the question of liability. An attorney may help to determine the need for contracts and liability insurance.

\section{How will members communicate with each} other? Newsletters, meetings, garden parties? Many languages are spoken in Florida, so translators may help with communication among garden members.

What will the garden be named? Having a name can help establish a sense of place and create an identity for the garden.

\section{The Role of Cooperative Extension}

It is up to the members of each community garden to perform their own fundraising, site preparation, materials purchasing, planting, maintenance, and harvesting. Among many other services, the Florida Cooperative Extension System provides education to enable community garden development throughout the state. Cooperative extension agents and Master Gardeners can provide educational assistance for community garden projects. An extension specialist, agent, or Master Gardener may be available on occasion for a garden site visit to assist community gardeners at key stages of garden development. Numerous horticultural extension publications are available on the internet and from county extension offices. With sufficient interest, extension workshops can be organized on a wide range of topics, from horticulture to irrigation system design, to food preservation and nutrition. 